\title{
Deyimlerin Hikâyesini Bilmenin Yedinci Sınıf Öğrencilerinin Yazılı Anlatımlarında Deyim Kullanımına Etkileri
}

The Effects of Knowing the Story of Idioms on the Use of Idioms in Their Written Expressions of Seventh Grade Students

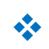 \\ Selda Tek \\ Uzman \\ Afyon Kocatepe Üniversitesi \\ seldatek42152@gmail.com \\ ORCID ID: 0000-0002-0386-108X \\ Bilal Uysal \\ Dr. Öğretim Üyesi \\ Afyon Kocatepe Üniversitesi \\ buysal@aku.edu.tr \\ ORCID ID: 0000-0002-7198-8760
}

\section{Makale Bilgisi / Article Information}

\author{
Makale Türü / Article Type : Araştırma Makalesi \\ Geliş Tarihi / Received : 29 Kasım 2021 \\ Kabul Tarihi / Accepted : 12 Aralık 2021 \\ Yayın Tarihi / Published : 15 Aralık 2021 \\ DOI Number : 10.20860/ijoses.1030001
}

Bu makale 2021 Yılında Bilal Uysal danışmanlığında tamamlanan "Deyimlerin Hikâyesini Bilmenin Yedinci

Sınıf Öğrencilerinin Yazılı Anlatımlarında Deyim Kullanımına Etkileri” Adlı Yüksek Lisans Tezinden üretilmiştir.

$$
*
$$

\section{Kaynak Gösterme / Citation}

Demirel, F. "Deyimlerin Hikâyesini Bilmenin Yedinci Sınıf Öğrencilerinin Yazılı Anlatımlarında Deyim Kullanımına Etkileri”. Uluslararası Sosyal ve Eğitim Bilimleri Dergisi, 16 (2021): 260274. 


\title{
Deyimlerin Hikâyesini Bilmenin Yedinci Sınıf Öğrencilerinin Yazılı Anlatımlarında Deyim Kullanımına Etkileri
}

\author{
The Effects of Knowing the Story of Idioms on the Use of Idioms in Their Written Expressions of \\ Seventh Grade Students
}

\section{Selda Tek \& Bilal Uysal}

Öz

Deyimler; az söz ile çok şey anlatan, kullanıldığında ifade gücümüze güç katan söz varlıklarımızdır. Özellikle son yıllarda Türkçe Eğitimi alanında deyimlerin öğretimi eğitimcilerin dikkatini çekmiştir. Alanda, deyimlerin öğretiminde kullanılabilecek çeşitli yöntem ve teknikler üzerine yapılan araştırmalara duyulan intiyaç da artmaktadır. Bu çalışmada deyim öğretiminde, deyimin hikâyesini ve gerçek anlamını bilmenin yazılı anlatımda söz varlığını artırmaya ve deyim kullanımına etkisinin olup olmadığı araştırılmıştır. Araştırmada ön test-son test kontrol gruplu random desen kullanılmıştır. Yapılan bağımlı örneklem t-testinden elde edilen sonuçlara bakıldığında öğrencilerin ön test puanları ile son test puanları arasındaki farklılı̆ın istatistiksel olarak \%95 güven düzeyinde anlamlı olduğu tespit edilmiştir ( $\mathrm{t}=-2.321$, $\mathrm{p}=.023, \mathrm{p}<.05)$. Öğrencilerin ön test puanlarının son test puanlarından düşük olduğu, dolayısıyla verilen eğitimin ya da oluşturulan algının öğrenciler üzerinde başarılı olduğu görülmüştür.

Anahtar Kelimeler: Deyim, deyimlerin öğretimi, söz varlığı, yazılı anlatım, bağlam.

\section{Abstract}

Idioms are the features of language that means something different than a literal translation of the words so that these features of language enriches the content of our language. That's why, particularly in recent years, the impact of teaching idioms integrating into the teaching Turkish as a native language has been recognized by educators and it has drawn the attention of researchers in the field. The need of study in research on the various methods and techniques that can be used during the process of teaching idioms is also on the rise. In this study of research, the significance of knowing the stories behind idioms and their accurate meaning has been analyzed to enhance the discourse of language and usage of them. Pre and past-test experimental design has been used through the whole procedure of research. Both groups are measured before and after the experimental groups is exposed to a treatment. With the enlightment of collected data, the benefits of having the knowledge of idioms and their actual meaning in our mental lexicon has been studied in terms of its efficacy on the written production of language. When the dependent sample t-test results were examined, it was determined that the difference between the students' pre-test scores and post-test scores was statistically significant at the $95 \%$ confidence level $(t=-2.321, p=.023, p<.05)$. It is seen that the pre-test scores of the students are lower than the post-test scores, so the education given or the perception created are successful on the students.

Keywords: Idioms, instruction of idioms, existence of words, written expression, context. 


\section{Giriş}

Dil, insanlar arasında iletişimi sağlayan en gelişmiş bildirişim aracıdır. Dilin temel taşı söz varlığı ise sınırlıdır. Ancak insanlar bu sınırlamayı kabul etmemiş, sınırlı sayıdaki sözcükle sonsuzu anlatmayı amaçlamıştır. Dilin millî kimliğinin ortaya çıkması ve bir millete ait kültür ögesi durumuna gelmesi de bu aşamada gerçekleşmektedir. Dil, insanların duygu ve düşüncelerini kodlayarak özneler arası iletişimi sağlayan sistemler bütünü olmanın yanı sıra yaşayan canlı bir varlıktır. Tüm canlıların türlerine özgü bir dil yapısı olduğu gibi her milletin de kendine özgü kodları vardır. Sülükçü (2011, s. 39)'ye göre seslerden kelimelerin, kelimelerden de önceden belirlenmiş sisteme göre cümlelerin oluşturulması bir şifreleme işlemidir ve her milletin şifreleme ve şifre çözme sistemleri birbirinden farklıdır. Bu şifreleme işleminde milletler, tarihleri boyunca yaşadıkları ortak tecrübeden beslenirler. Bir toplumun uzun bir zaman diliminde bazen bilinçli bazen bilinçsiz oluşturduğu ve oluşturmaya devam ettiği dil, söz konusu toplumu birleştiren, koruyan ve onun kalıcılığını sağlayan önemli bir kültür ögesi hâline gelir.

Dilin düşünce ile iç içe olması gerçeğinden yola çıkılarak hayatın her alanında var olduğu sonucuna varılır. Her alanla ilgisi bulunan dile yönelik araştırmalar da çok yönlü olmuştur. Gelişmiş bir iletişim aracı olan dil üzerine çalışan her araştırmacı dili farklı bir yönüyle tanımlamıştır. Yapılan bu tanımlara bakıldığında dilin çok yönlülügünü görmek mümkündür. Banguoğlu (1979, s. 17) dilin en güzel anlatım aracı olduğunu ifade eder. Ergin'e göre dil, "Seslerden örülmüş sosyal bir müessesedir" (1972, s. 1). Aksan (2015, s. 11); dili, birçok konuyla, alanla ve kavramla ilişkisi olan, değişik açılardan incelendiğinde çeşitli özelliklere sahip olduğu görülen, hâlâ çözümlenemeyen yönleri bulunan olağanüstü bir varlık olarak görür. Dili, insan ve toplum ile bir bütün olarak gören dil araştırmacıları da vardır. Korkmaz (1995, s. 2)'a göre dil, ayrıntılarına bakıldıkça; insan, millet ve kültür varlığına egemen olan çok nitelikli ve derin manalı bir sistemdir. Yıldız (2013, s. 9), dilin insanın sahip olduğu en değerli özellik olduğunu söyler.

Bireyin sahip olduğu ilk dil ana dilidir. Yakın çevreden edinilen bu dilin zamanla konuşucusu hâline gelen birey ait olduğu toplum ile bağlarını bu dil sayesinde güçlendirir.

\section{Ana Dili ve Ana Dili Eğitimi}

İnsan, dili kullanma becerileri açısından kusursuz bir donanıma sahip olarak doğar. Birey doğuştan gelen bu donanım ile çevresinde hazır hâlde bulunan söz varlığını, kavramları ve dil bilgisi kurallarını edinmeye başlar. "Ana dili; insanın zihnine o farkında olmadan içinde doğup büyüdüğü çevresi tarafından işlenen dil kuralları ve söz varlığıdır. Kişinin edindiği ilk dildir.” (Yakıcı, 2017, s. 7). Aksan (2016, s. 20)'a göre insan her şeyden önce edindiği ana dili ile dünyayı tanır. Ana dilinin imkânlarıyla düşünür, onun kavramlarıyla evreni biçimlendirir. İnsan birden fazla yabancı dil öğrenebilmesine karşın duygularını ana diliyle yaşar, onunla düşünür. Yaşam boyu öğrendiği her şeyi ana dilinin üzerinde inşa eder. Bilgin (2002, s. v)'e göre bu durum çocuk beyninin zorlanmadan, kendine sınırlar koymadan, özgürce yol alacağı tek alanın anadili olmasından kaynaklıdır.

Ana dili bireyin çevresiyle iletişim kurmasını; çevresinde meydana gelenleri, gördüklerini ve işittiklerini anlamlandırmasını sağlar. Yıldız (2013, s. v), bireyin kendisinde var olan bilgileri değerlendirebilmesinin, yeni öğrendiklerinin ise yorumlayabilmesinin; hissettikleriyle ve düşündükleriyle kendini iyi ifade edebilmesinin de ana dille gerçekleştirilebileceğini bildirir. Çocuğun benlik bütünlüğünü kazanması ve kimlik oluşumunu tamamlaması da ana dili eğitimine bağlıdır. Aile ve yakın çevreden edinilen bu ilk dilin çocuğa aktarımında kusursuz bir edinim sürecinden bahsetmek mümkün değildir. Ana dilindeki söz varlığı, dil kurallarının yanı sıra mevcut hâldeki dil yanlışları da 
edinim sürecine dâhil olur. Bundan dolayı okullarda ana dili öğretimi yapılmaktadır. Dili doğru ve yerinde kullanmada ana dilinin doğru öğretimi üzerine düşünen Özbay (2013, s. 5), dilin iki boyutu olduğunu bildirir. Bunlar, anlama ve anlatma boyutlarıdır. Bu becerilerin edinimi, bireyin örgün eğitime geçmeden önce içinde bulunduğu çevrede başlarken becerilerin planlı bir biçimde öğretimi okulda başlar.

Çocukların ana dili edinimleri ilk olarak dinleme ile gerçekleşir. Dil edinimi bireyin dünyaya gelişi ile birlikte başlayan, kendiliğinden kazanılan, herhangi bir çaba gerektirmeyen bir süreçtir. Birey bu süreç boyunca ana diline ait kuralları doğal olarak edinir, benimser. Böylece çocuk ana dilini kurallarına uygun olarak kullanma becerisini örgün eğitime başlamadan önce kazanır. Kendiliğinden gerçekleşen ve her türlü etkiye açık olarak edinilen bu kazanımlar ana dili edinimidir. Ana dili ögretimi ise yakın çevrede kendiliğinden işleyen bu edinim sürecinin ardından eğitim kurumlarında plan ve program dâhilinde belirli amaçların kazanımına yönelik yürütülen sistematik ve kasıtlı etkinlikler bütünüdür. Yıldız (2013, s. 46), ebeveynler ve eğitimcilerin dille yeni tanışan bir çocuğa dilin inceliklerini, kurallarını yerleştirmek için açıkça ve gizlice ana dilini öğretme çabası içine girdikleri görüşündedir. Yıldız bu görüşüyle edinimde de bir kasıt ve istendik davranış kazandırma süreci olduğu vurgusunu yapar. Bundan dolayı ana dili öğretimi veya ana dili edinimi terimlerinin yerine göre kullanılmasının uygun olduğu düşüncesindedir.

Türkçe Dersi Öğretim Programı'nda yer verilen amaçlara bakıldığında ana dili eğitiminin çok amaçlı bir yapıya sahip olduğu görülür. Belirtilen amaçların öğrenciye kazandırılması sürecinde gerçekleştirilen uygulamalar da çok yönlü olmaktadır. Aytaş ve Çeçen (2010, s. 79)'e göre okuduğunu ve dinlediğini anlama, sözel anlatım, yazarak anlatma, dil bilgisi, kelime çalışmaları, edebiyat sanatının ilkelerini öğrenme ve edebî eserleri anlayıp değerlendirme bu uygulamalar arasında sayılabilir. Ana dili eğitiminin nihai amacı ise temel dil becerilerinin birey tarafından etkili bir şekilde kullanılmasını sağlamaktır. Temel beceriler ile söz varlığı arasında anlamlı bir ilişki var olduğundan dolayı Türkçe Dersi Öğretim Programı'nda yer alan söz varlığının zenginleştirilmesine yönelik kazanımlar bu amaca hizmet etmektedir.

\section{Söz Varlığı}

Dil, parçaların bir araya gelmesiyle oluşmuş bir bütündür. Bu bütünü oluşturan parçalar söz varlığ1 olarak adlandırılır. Korkmaz (1992, s. 100); (bk. kelime hazinesi) söz varlığını bir dilin bütün kelimeleri, bir kişinin veya bir topluluğun söz dağarcığında yer alan kelimeler toplamı şeklinde tanımlamıştır. Ait olduğu dilin beslendiği kültürden izler taşıyan söz varlıkları toplumların, düşünce yapılarını yansıtmanın yanı sıra tarihindeki toplumsal gelişmelerle de değişime uğramıştır. Aksan (2006b, s. 11), söz varlığının ait olduğu dilin tarihine 1şık tuttuğunu belirtir. Yüzyıllar boyunca ortaya çıkan biçim ve anlam değişiklikleri, hangi dillerin etkisiyle nasıl bir değişim geçirdiğini yansıtmaktadır. Bundan dolayı bir milletin tarihi ne kadar köklü ise söz varlığı o denli geniştir.

Türk dili çok köklü bir dildir; köklü bir geçmişe sahip olmanın yanında zengin bir kültürden beslenmiştir. Bu nedenle zengin bir söz varlığına sahiptir. Türkçenin sahip olduğu söz varlığı bir bütün olarak incelenecek olursa, dünyanın en eski dillerinden biri olduğunun anlaşılacağını belirten Aksan (2006a, s. 17), günümüzde canlılığını koruyan iki bin civarında atasözünün varlığını bildirir. Bu konuda Hengirmen (2011a, s. 6), Türkçe deyimler üzerine yaptığı çalışmaların neticesinde Türkçede yaklaşık on bin deyimin var olduğu sonucuna ulaşmıştır. Söz varlığını oluşturan ögeler bunlarla da sınırlı değildir. Aksan (2006b, s. 13-14), dilin kendi ögelerinden oluşan kimi zaman da yabancı dillerden alıntıladığımız temel söz varlı̆̆ı, dildeki diğer sözcüklerin yanı sıra bilim ve sanat gibi alanların kavramları olan terimleri söz varlığının içerisindeki ögeler olduğunu söyler. Aksan'a göre bir 
durumu veya bir olayı betimlemek için kullanılan deyimler, her dilde bulunan ve yaşam tecrübeleri içeren atasözleri, insanların toplum yaşamlarında kullandıkları ilişki sözleri (kalıp sözler), kalıplaşmış sözlerin yanı sıra anlatım gücüne güç katan ikilemeler de söz varlığı içerisinde değerlendirilir. Aksan'ın bu sınıflamasına ek olarak Ünalan (2010, s. 109-110), söz varlığının önemli bir kısmını oluşturan argo ve bir grup kişinin anlayabildiği, zamandan tasarruf için kullanılan jargon da söz varlığını oluşturan unsurlardan birisi olduğunu söyler. Söz varlığını oluşturan bu ögeler gerek sözlü iletişimde gerek yazılı anlatımda anlamayı kolaylaştırmanın yanı sıra anlatımı da güçlendirmektedir.

\section{Yazılı Anlatımda Söz Varlığı Kullanımı}

Yazılı anlatım düşünmeyle başlayan ve bilişsel bir hazırlık gerektiren anlatım biçimidir. Düşünmeye başlayan birey bu işlemi söz varlığının sınırları içerisinde gerçekleştirebilir. "Kelime hazinesi dili kullanan bireylerin hem akademik hem de gündelik hayatta anlama ve anlatma becerilerinin sınırlarını belirlemektedir." (Özbay, 2013, s. 101). Bireyin duygu, düşünce ve isteklerini doğru bir şekilde ifade edebilmesi için edindiği veya öğrendiği söz varlığının anlatıma elverişli düzeyde olması gerekir. Korkmaz (1995, s. 184)'a göre konuşma veya yazmada anlatımın işlek, açık ve etkili olması için kişi ana dilini iyi kullanmalıdır.

Bireyin sahip olduğu söz varlığı iki bölümden oluşmaktadır. Bunlar aktif ve pasif söz varlıklarıdır. Baş (2006, s. 105)'a göre yazma ve konuşma becerileri ile gerçekleştirilen anlatım sırasında bireyin kullandığı sözcüklerin toplamı üretici söz varlığını diğer bir adıyla aktif söz varlığını oluşturur. Anlama (okuma ve dinleme/izleme) etkinlikleri sırasında kullanılan sözcükler ise alıcı söz varlığı diğer bir adıyla pasif söz varlığı olarak adlandırılır. Pasif söz varlığının aktif söz varlığına göre daha geniş olduğu bilinmektedir. Anlamaya dayalı beceriler pasif söz varlığını geliştirirken anlatmaya dayalı beceriler aktif söz varlığından beslenir. Konuşma gibi yazma becerisi de aktif söz varlığı üzerine kurulur. Yalçın (2018, s. 361), yazma becerisinin gelişmesi için aktif söz varlığı ile pasif söz varlığ arasındaki açığın azaltılması ve genel olarak söz varlığının da genişletilmesinin gerekliliğine vurgu yapar. Ana dili dersinde söz varlığını geliştirmeye yönelik planlanan etkinlikler hazırlanırken beceriler arası koşutluk göz önünde bulundurulmalıdır. Okuma ve dinleme/izleme etkinliklerine paralel olarak yazma ve konuşma etkinliklerinin yaptırılması bu koşutluğu sağlamanın bir yoludur. Böylelikle okuma yoluyla pasif söz varlığına eklenen sözcük, yazma etkinliğiyle aktif söz varlığına geçebilir.

Yazılı anlatımda, anlatımı güçlü kılmak için kullanılan söz varlığının alt dallarından biri de deyimlerdir. Dolayısıyla söz varlığını zenginleştirmeye yönelik gerçekleştirilen etkinlikler kapsamında deyim öğretimi çalışmaları önemli bir yere sahiptir.

\section{Deyimler ve Deyim Öğretimi}

İnsan zekâsının dile yansıyan yönü olan deyimler bir duyguyu, düşünceyi dile getirmek veya bir durum ya da olayı en az çaba ile betimlemek için kullanılan söz varlığıdır. Dildeki her sözcük, iletişimde oluşan bir boşluğu gidermek için türetilir. Her sözcüğün var edilmesinde bir amaç vardır. Günay (2007, s. 87), dildeki her sözcügün bir değeri, anlatımda gerçekleştirmesi beklenen bir işlevi olduğu düşüncesindedir. Kavas (1991, s. 13)'a göre deyimlerin de temel işlevi bir hâli ifade etmektir. Deyimler toplumların anlatımda kullandıkları vazgeçilmez ifadelerdir. Deyimler olmadan konuşmanın mümkün olmayacağını bildiren Hengirmen, "Atasözleri konuşmamıza zenginlik katar. Ama atasözlerini konuşmamızda kullanmazsak önemli bir eksiklik hissetmeyiz. Ancak deyimler hayatımıza öyle girmiştir ki çoğu zaman deyimleri açıklarken bile başka bir deyime gerek duyarız" (2011a, s. 6) diyerek deyimlerin vazgeçilmez söz varlıkları olduğu vurgusunu yapar. 
Dili etkili bir şekilde kullanmak isteyen konuşucu, dilin kendisine verdiği bütün imkânları kullanabilmelidir. Bundan dolayı konuşucu her şeyden önce dilinin imkânlarını, inceliklerini ve mantığını iyi bilmelidir. Anlatımı güçlü kılmak için dilin verdiği imkânların başında deyimler gelmektedir. "Sözvarlığının önemli bir bölümünü oluşturan deyimler, bir dilin çeşitli özelliklerini yansıttığı gibi, dile iyice egemen olabilmek için öğrenilmesi, bilinmesi gerekli olan sözlerdir; dilbilgisiyle, sözcükleriyle bir dil iyice öğrenilmiş olsa bile, deyimleri öğrenilmedikçe çaba eksik kalır” (Aksan, 2015/III, s. 35). Deyimler mecazlı ve soyut anlamlı söz varlıkları olduğundan diğer söz varlıklarına nispeten deyimlerin öğretimi konusuna ayrıca dikkat edilmesi gerekir. Deyimlerdeki bu mecazlı anlatım ve soyut anlamlılık, deyim öğretiminde kullanılacak yöntemin belirlenmesini önemli kılmaktadır. Yöntem seçiminin yanı sıra dikkat gerektirecek bir husus da öğretilen deyimlerin pasif söz varlığında kalmayıp aktif söz varlığına aktarılması olmalıdır. Çünkü deyimler hem anlama hem anlatma becerilerini geliştiren kalıplaşmış ifadelerdir.

Deyimlerin, tıpkı diğer söz varlıkları gibi, yerli yerinde yani doğru bağlamda kullanılması için doğru anlamlandırılmaları gerekir. Ancak "Bir söz öbeğinin, deyim olabilmesi için öylesi bir anlam boyutuna geçmesi gerekir ki, artık o anlam boyutunu deyimler sözlüğü dışındaki sözlüklerde bulamazsınız" (Akyalçın, 2012, s. 11). Bundan dolayı deyimler, anlamlandırılması zor söz varlıklarındandır. Deyimlerin bağlamlarıyla birlikte verilmesi bu söz varlıklarının öğrenciler tarafından anlamlandırılmasını kolaylaştıracaktır. Bağlam, bir dil ögesinin ilişki içinde bulunduğu diğer ögelerle ve kullanıldığı ortamla oluşturdukları anlamsal bütünlüktür. Saussure ile birlikte dilin bir dizge olduğu görüşünün kabul görmesinin ardından dilbilimciler bağlam kavramına önem vermişlerdir. Bağlam konusunda "1950'lerde derinleşen Z. S. Harris, tümcenin, bir düşüncenin anlatılmasında yeterli olmadığını belirlemekte, dilce adını verdiği, tümceden büyük söz parçalarının kendilerine özgü yapı özellikleri olduğuna değindikten sonra bir tümceden çıkacak anlamın, dilcenin bütün parçalarının birbirleriyle olan karşılıklı ilişkileriyle aydınlatılabileceğini ileri sürmekteydi”" (Aksan, 2015/III, s. 202). Ana dili öğretmenlerinin deyim kullanan kişiler olması hem deyimleri öğrenciye sezdirmede hem öğrencileri deyim kullanımı için güdülemede hem de deyimlerin doğru bağlamlarını öğrenciye hatırlatmada çok önemli bir yere sahiptir.

Literatürde deyimlerin öğretimi konusunda yapılan çalışmalara bakıldığında deyimlerin öğretiminde birçok yöntemin etkililiğinin sorgulandığı görülür. Metinsel bağlamın etkisini sorgulayan Balaban, "Deyim bakımından söz varlığı edinme sürecinde kitap okumanın etkisi dikkate değer düzeydedir. Öğrencilere kitap bağlamında birinci, ikinci ve üçüncü düzey deyimler sunulabilir ve bu deyimleri özgün tümcede kullanmaları sağlanabilmektedir. Kitap bağlamının sunulamaması durumunda ise, deyimlerin bir tümce bağlamında sunulması gerekmektedir. Bağlam olmaksızın deyim öğretiminde başarı, istenen düzeyde olamamaktadır" (2019, s. 62) sonucuna ulaşmıştır. Benzer düşüncede olan Emir (1974, s. 5)'e göre deyimlerin oluşum hikâyeleri bilinirse anlamları bütün ayrıntılarıyla kavranılmış olur. Gülcan (2010, s. 67), deyim öğretiminde kullanılan gösteri tekniğinin etkililiğini sorgulamıştır. Deyimin kullanıldı̆̆ı bağlamı resim ya da karikatür ile yansıtan araştırmacı elde ettiği veriler neticesinde; gösteri tekniği ile gerçekleştirilen deyim öğretiminin, geleneksel öğretim yöntemi ile gerçekleştirilen deyim öğretimine göre daha etkili olduğu sonucuna ulaşmıştır. Deyimlerin öğretiminde aktif öğrenme tekniklerinin, ilköğretim 8. sınıf öğrencilerinin deyimleri öğrenmeleri üzerine etkisini araştıran Özbay ve Akdağ, "deyimlerin gülmeceli bir Keloğlan masalı içerisinde sunulması ve buna dayalı olarak yapılan çalışmalar bunların öğrencilerin zihninde daha kalıcı olmasını" (2013, s. 53) sağladığg sonucuna ulaşmışlardır. İlköğretim ikinci kademe öğrencilerinin söz varlığını atasözü ve deyimlerle zenginleştirirken dramatizasyon yönteminin ne derece etkili olduğunu sorgulayan Kazıcı (2008, s. 61)'nın araştırmasında deney grubunun son test puan ortalamaları ön test 
puan ortalamalarından anlamlı düzeyde yüksek bulunmuştur. Dramatizasyon yöntemi deney grubunun deyim ve atasözlerini öğrenmesinde anlamlı düzeyde etkili olduğu sonucuna ulaşılmıştır.

Bu araştırmanın amacı, yedinci sınıf Türkçe dersi deyim öğretiminde, deyimin hikâyesini ve gerçek anlamını bilmenin yazılı anlatımda söz varlığını zenginleştirmeye ve deyim kullanımına etkisinin olup olmadığını ortaya koymaktır. Bu amaca yönelik olarak araştırmada şu sorulara yanıt aranmıştır.

1. Deyimlerin hikâyesini bilmenin yedinci sınıf öğrencilerinin yazılı anlatımlarında deyim kullanımına etkisi nedir?

2. Deyim öğrenimindeki akademik başarı ile yazılı anlatımda deyim kullanımı arasında ilişki var midir?

3. Deyim öğretiminde deyimin hikâyesini ve gerçek anlamını bilmenin yazılı anlatımdaki etkilerinde cinsiyete göre fark var mıdır?

\section{Yöntem}

\section{Araştırmanın Modeli}

Araştırmada nicel araştırma yöntemlerinden gerçek deneysel bir yöntem olan ön test-son test kontrol gruplu desen kullanılmıştır. Ekiz (2003, s. 99)'e göre deneysel araştırma yöntemi bir çalışmada herhangi bir nesne, kişi, olay ve bu olayın gerçekleşmesine yol açan etkenleri inceleyerek değişkenler arasındaki neden-sonuç ilişkilerini belirlemek ve neticeleri kıyaslayarak ölçmek amacıyla yapılan araştırmadır. Bu yönteme duyulan gereksinimin temel nedeni, merak edilen herhangi bir yöntemin etkili olma durumunu ölçmek, ölçüm neticesi olumlu ise bundan faydalanılarak önerilerde bulunmaktır.

Tablo 1. Araştırma Modeli

\begin{tabular}{|c|c|c|c|}
\hline & Ön Test & Uygulama & Son Test \\
\hline \multirow{5}{*}{ Deney Grubu } & Başarı Testi & \multirow{5}{*}{$\begin{array}{l}\text { İki Dirhem Bir Çekirdek (Pala: 2018) } \\
\text { adlı kitap okutulmuştur. }\end{array}$} & Başarı Testi \\
\hline & Yaz1 1 & & Yazı 1 \\
\hline & Yazı 2 & & Yazı 2 \\
\hline & Yazı 3 & & Yaz1 3 \\
\hline & Yaz1 4 & & Yaz1 4 \\
\hline \multirow{5}{*}{ Kontrol Grubu } & Başarı Testi & \multirow{5}{*}{ Herhangi bir işlem yapılmamıştır. } & Başarı Testi \\
\hline & Yazı 1 & & Yazı 1 \\
\hline & Yaz1 2 & & Yaz1 2 \\
\hline & Yaz1 3 & & Yaz1 3 \\
\hline & Yaz1 4 & & Yaz1 4 \\
\hline
\end{tabular}

Kullanılan model gereği seçkisiz atama yöntemi ile iki grup oluşturulmuştur (Tablo 1). Oluşturulan bu grupların birine deney grubu diğerine de kontrol grubu denilmiştir. Her iki gruba, ön test kapsamında deyimlerle ilgili bir başarı testi uygulanmış, ardından dört farklı konuda yazılı anlatım uygulaması yaptırılmıştır. Uygulama aşamasında sadece deney grubuna deyimler ve bu deyimlerin hikâyeleri hakkında bilgi veren İki Dirhem Bir Çekirdek adlı eser okutulmuştur. Okuma işlemi tamamlandıktan sonra her iki gruba son test kapsamında başarı testi uygulanmış, ardından başta belirlenen dört konuyla ilgili yazılı anlatım uygulaması yaptırılmıştır. 


\section{Çalışma Grubu}

Çalışmada, seçilen model gereği, iki farklı grup oluşturulmuştur. Deneysel yöntemde bu gruplar deney ve kontrol grupları olarak adlandırılmaktadır. Ekiz (2003, s. 98), kontrol grubunu deneysel araştırmalarda işleme tabi tutulmayan, deney grubundaki değişmeyi ortaya koymak amaciyla karşılaştırma yapmaya yarayan katılımcıların oluşturduğu grup olarak açıklarken; deney grubunu ise işleme tabi tutulan, üzerinde deneyin yapıldığı (yeni bir uygulama, yeni bir ürün vb.) katılımcıların oluşturduğu grup olarak tanımlar. Bir araştırmanın deneysel olmasının temel koşulu, grupların deneysel işlem koşullarının random atanmış olmasıdır. Deneysel desen temel koşulunu sağlamak adına çalışma grubu seçimi yapılırken deney ve kontrol grupları olarak Konya merkezde random seçilen bir ortaokulda rast gele iki 7. sınıf araştırmaya dâhil edilmiştir. Araştırma kırk kontrol, kırk deney olmak üzere seksen katılımcı ile gerçekleştirilmiştir. Araştırma kapsamındaki öğrencilerin demografik özelliklerinin dağılımı incelendiğinde, \%46,3'ünün kız, \%53,8'inin erkek olduğu belirlenmiştir.

\section{Veri Toplama Araçları}

Yapılan araştırmada veri toplamak için başarı testi kullanılmıştır. Maksimum performans testleri grubuna dâhil olan başarı testleri, okul ortamında verilen akademik programın ardından öğrencilerde görülen değişimi saptama amacı ile kullanılan testlerdir. Bu testler kişinin programdan ne derecede yararlandığının göstergesidir. Akademik başarı testi; on beş çoktan seçmeli, otuz boşluk doldurma ve dört açık uçlu sorudan oluşmaktadır. Sorular araştırmacı tarafından hazırlanmıştır. Teorideki bilginin uygulamadaki yansımalarını ölçmek için ayrıca dört farklı konuda yazılı anlatım uygulaması yaptırılmıştır.

\section{Verilerin Toplanması ve Analizi}

Bağımsız değişken durumundaki etkisi araştırılan deyim öğretim yönteminin uygulanmasından önce ve sonra deney ve kontrol gruplarına ön test ve son test uygulanmıştır. Ön test ve son test bir başarı testinden ve dört yazılı kompozisyon uygulamasından oluşmaktadır. Başarı testi ile öğrencilerin deyimler hakkında teorik bilgileri ölçülmüştür. Yazılı kompozisyon uygulamasındaki amaç ise deyimler hakkındaki bu teorik bilgilerin yazılı anlatım kapsamında pratikte kullanabilme becerilerini araştırmaktır. Çalışmada elde edilen bütün verilerin istatistiksel analizleri IBM SPSS 25.0 programı ile yapılmıştır. Araştırmada ilk olarak veri toplama araçlarının normal dağılım hipotezine uyup uymadığı saptanmıştır. "Veriler her zaman normal dağılıma uygun olmayabilir. Gözlenen her veri kümesi için normal dağılıma uygun olduğunu varsayarak istediğimiz istatistiksel sonuçları elde etmeye çalışırsak uygulamada yanıltıcı ve çelişkili durumlarla karşılaşılır. Bu amaçla hata yapmamak ve bilinçli olmak için bir veri kümesinin hangi dağılıma uygun olduğunu bilmek gerekir" (Çelik, 2006, s. 11). Verilerin normal dağılım hipotezine uygunluğunun saptanmasının ardından parametrik test yöntemleri seçilmiştir (Tablo 2). Daha sonra veri toplama araçlarının güvenilirliği sorgulanmış ve ardından tanımlayıcı istatistikler verilmiştir. Araştırmanın sonunda varsayımların değerlendirmesi yapılmıştır. Değerlendirme sürecinde üç yöntem tercih edilmiştir. Bunlar: Bağımsız örneklem t testi, bağımlı örneklem t testi ve pearson korelasyon analizidir. Ulaşılan neticeler istatistikî anlamlılık $\mathrm{p}<0,05$ düzeyinde değerlendirilmiştir.

\section{Araştırmanın Etik Boyutu}

Araştırma öncesinde Afyon Kocatepe Üniversitesi Sosyal ve Beşeri Bilimler Araştırma ve Yayın Etik Kurulundan 11.12.2019 tarihli, 2019/124 sayılı etik kurul onayı alınmıştır. 


\section{Bulgular}

Katılımcı Test Puanlarından Elde Edilen En Düşük Puan, En Yüksek Puan, Ortalama Puan ve Standart Sapmaya Dair Bulgular

Tablo 2. Katılımeı Test Puanlarından Elde Edilen Sonuçlara Dair Bulgular

\begin{tabular}{lccccc}
\hline & N & Min & Max & Ortalama & Std.Sapma \\
\hline Ön Test Puan & 80 & 9 & 62 & 32,66 & 10,946 \\
\hline Son Test Puan & 80 & 2 & 91 & 36,83 & 16,47 \\
\hline Ön Test Deyim Puan & 80 & 0 & 15 & 4,99 & 3,22 \\
\hline Son Test Deyim Puan & 80 & 0 & 10 & 4,36 & 2,377 \\
\hline
\end{tabular}

Araştırmaya katılan öğrencilerin akademik başarı testi ön test ortalaması $32.66 \pm 10.95$, en az 9 en fazla 62 puan tespit edilmiştir. Araştırmaya katılan öğrencilerin akademik başarı testi son test ortalamas1 $36.83 \pm 16.47$, en az 2 en fazla 91 puan tespit edilmiştir.

Araştırmaya katılan öğrencilerin yazılı anlatımda kullanılan ön test deyim ortalaması $4.99 \pm 3.22$, en az 0 ve en fazla 15 puan olarak belirlenmiştir. Araştırmaya katılan öğrencilerin yazılı anlatımda kullanılan son test deyim ortalaması $4.36 \pm 2.38$, en az 0 en fazla 10 puan olarak belirlenmiştir.

Verilerin Dağılımına Ait Normallik Testleri Sonuçlarına Dair Bulgular

Tablo 3. Verilerin Dağılımına Ait Normallik Testleri Sonucu

\begin{tabular}{lccccccc}
\hline & İstatistik & sd & $\mathbf{p}$ & Ortalama & Medyan & Çarpıklık & Basıklık \\
\hline Ön Test Puan & 0,051 & 80 & 0,200 & 32,66 & 32 & 0,211 & 0,129 \\
\hline Son Test Puan & 0,120 & 80 & 0,006 & 36,83 & 34,50 & 0,330 & $-0,039$ \\
\hline Ön Test Deyim Puan & 0,106 & 80 & 0,025 & 4,99 & 5 & 0,751 & 0,584 \\
\hline Son Test Deyim Puan & 0,186 & 80 & 0,000 & 4,36 & 4 & 0,587 & $-0,197$ \\
\hline
\end{tabular}

George ve Mallery (2010), normal dağ 11 ım analizi neticesinde ortalama ve ortancanın birbirine yakın olması; basıklık ile çarpıklığın \pm 2 arasında değer alması gerektiğini bildirir.

Değiş̧kenlere göre araştırma sonucunda elde edilen değerlerin de normal dağılıma uyduğu belirlenmiştir. Böylelikle çalışma için normal dağılım analizlerinin uygulanması kararlaştırılmıştır.

Katılımcı Test Puanlarının Cinsiyetlere Göre Farklılığına Ait Analiz Sonuçlarına Dair Bulgular

Tablo 4. Katılımcı Test Puanlarının Cinsiyetlere Göre Farklılığına Ait Analiz Sonuçları

\begin{tabular}{|c|c|c|c|c|c|c|c|}
\hline & Cinsiyet & $\mathbf{N}$ & Ort. & Std.Sapma & $\mathbf{t}$ & sd & $\mathbf{p}$ \\
\hline \multirow{2}{*}{ Ön Test Puan } & $\mathrm{K}_{1 \mathrm{z}}$ & 37 & 35,84 & 11,413 & \multirow{2}{*}{2,484} & \multirow{2}{*}{78} & \multirow{2}{*}{$* 0,015$} \\
\hline & Erkek & 43 & 29,93 & 9,859 & & & \\
\hline \multirow{2}{*}{ Son Test Puan } & $\mathrm{K}_{1 \mathrm{Z}}$ & 37 & 37,27 & 16,336 & \multirow{2}{*}{0,223} & \multirow{2}{*}{78} & \multirow{2}{*}{0,824} \\
\hline & Erkek & 43 & 36,44 & 16,768 & & & \\
\hline \multirow{2}{*}{$\begin{array}{l}\text { Ön Test Deyim } \\
\text { Puan }\end{array}$} & $\mathrm{K}_{1 \mathrm{Z}}$ & 37 & 5,73 & 3,548 & \multirow{2}{*}{1,946} & \multirow{2}{*}{78} & \multirow{2}{*}{0,055} \\
\hline & Erkek & 43 & 4,35 & 2,794 & & & \\
\hline \multirow{2}{*}{$\begin{array}{l}\text { Son Test Deyim } \\
\text { Puan }\end{array}$} & $\mathrm{K} 1 \mathrm{z}$ & 37 & 5,14 & 2,79 & \multirow{2}{*}{2,812} & \multirow{2}{*}{78} & \multirow{2}{*}{$* 0,009$} \\
\hline & Erkek & 43 & 3,7 & 1,726 & & & \\
\hline
\end{tabular}


Öğrencilerin test puanlarının cinsiyetlerine göre farklılık gösterip göstermediğini belirlemek için bağımsız örneklem t-testi yapılmıştır.

Kız öğrencilerin ön test puanlarının (ort=35.84), erkek öğrencilerinin ön test puanlarından (ort=29.93) yüksek olduğu görülmektedir.

Kız öğrencilerin son test deyim puanlarının (ort=5.14), erkek öğrencilerinin son test deyim puanlarından (ort=3.7) yüksek olduğu görülmektedir.

Katılımcı Test Puanlarının Gruplara Göre Farklılığına Ait Analiz Sonuçlarına Dair Bulgular

Tablo 5. Katılımcı Test Puanlarının Gruplara Göre Farklılığına Ait Analiz Sonuçları

\begin{tabular}{|c|c|c|c|c|c|c|c|c|}
\hline & & Grup & $\mathbf{N}$ & Ort. & Std.Sapma & $\mathbf{t}$ & sd & $\mathbf{p}$ \\
\hline \multirow{2}{*}{\multicolumn{2}{|c|}{ Ön Test Puan }} & Kontrol & 40 & 30,18 & 9,497 & \multirow{2}{*}{$-2,075$} & \multirow{2}{*}{78} & \multirow{2}{*}{$* 0,041$} \\
\hline & & Deney & 40 & 35,15 & 11,825 & & & \\
\hline \multirow{2}{*}{\multicolumn{2}{|c|}{ Son Test Puan }} & Kontrol & 40 & 36,28 & 16,683 & \multirow{2}{*}{$-0,297$} & \multirow{2}{*}{78} & \multirow{2}{*}{0,767} \\
\hline & & Deney & 40 & 37,38 & 16,448 & & & \\
\hline \multirow{2}{*}{$\begin{array}{l}\text { Ön } \\
\text { Puan }\end{array}$} & \multirow[t]{2}{*}{ Deyim } & Kontrol & 40 & 5,9 & 3,334 & \multirow{2}{*}{2,628} & \multirow{2}{*}{78} & \multirow{2}{*}{$* 0,01$} \\
\hline & & Deney & 40 & 4,08 & 2,859 & & & \\
\hline \multirow{2}{*}{$\begin{array}{l}\text { Son } \\
\text { Puan }\end{array}$} & \multirow[t]{2}{*}{ Deyim } & Kontrol & 40 & 4,68 & 2,314 & \multirow{2}{*}{1,179} & \multirow{2}{*}{78} & \multirow{2}{*}{0,242} \\
\hline & & Deney & 40 & 4,05 & 2,428 & & & \\
\hline
\end{tabular}

$* \mathrm{p}<0.05$

Öğrencilerin test puanlarının gruba göre farklı1ık gösterip göstermediğini belirlemek için bağımsız örneklem t-testi yapılmıştır.

Deney grubu ön test puanlarının (ort=35.15), kontrol grubu ön test puanlarından (ort=30.18) yüksek olduğu görülmektedir.

Kontrol grubu ön test deyim puanlarının (ort=5.9), deney grubu ön test deyim puanlarından (ort=4.08) yüksek olduğu görülmektedir.

Katılımcı Ön Test ve Son Test Puanları Arasındaki Farklılığa Ait Analiz Sonuçlarına Dair Bulgular

Tablo 6. Katılımcı Ön Test ve Son Test Puanları Arasındaki Farklılığa Ait Analiz Sonuçları

\begin{tabular}{|c|c|c|c|c|c|c|c|}
\hline & & $\mathbf{N}$ & Ort. & Std.Sapma & $\mathbf{t}$ & sd & p \\
\hline \multirow[t]{2}{*}{ Çift 1} & $\begin{array}{l}\text { Ön Test } \\
\text { Puan }\end{array}$ & 80 & 32,66 & 10,946 & \multirow[t]{2}{*}{$-2,321$} & \multirow[t]{2}{*}{79} & \multirow[t]{2}{*}{$* 0,023$} \\
\hline & Son Test Puan & 80 & 36,83 & 16,47 & & & \\
\hline \multirow{2}{*}{ Çift 2} & $\begin{array}{l}\text { Ön Test Deyim } \\
\text { Puan }\end{array}$ & 80 & 4,99 & 3,22 & \multirow{2}{*}{1,762} & \multirow{2}{*}{79} & \multirow{2}{*}{0,082} \\
\hline & $\begin{array}{l}\text { Son Test Deyim } \\
\text { Puan }\end{array}$ & 80 & 4,36 & 2,377 & & & \\
\hline
\end{tabular}

$* \mathrm{p}<0.05$

Öğrencilerin ön test ve son test puanları arasında farklılık olup olmadığını belirlemek için bağımlı örneklem t-testi yapılmıştır.

Öğrencilerin ön test puanlarının (ort=32.66), son test puanlarından (ort=36.83) düşük olduğu görülmektedir. 
Katılımcı Ön Test-Son Test Puanları Arasındaki İlişkiye Ait Korelasyon Analizi Sonuçlarına Dair Bulgular

Tablo 7. Katılımcı Ön Test Puanları-Son Test Puanları Arasındaki Korelasyon Sonuçları

\begin{tabular}{lcc}
\hline & & Son Test Puan \\
\hline \multirow{3}{*}{ Ön Test Puan } & $\mathrm{r}$ &, $371^{* *}$ \\
\cline { 2 - 3 } & $\mathrm{p}$ & 0,000 \\
\cline { 2 - 3 } & $\mathrm{N}$ & 80 \\
\hline
\end{tabular}

$* * p<0.01$

Öğrencilerin ön test puanları ile son test puanları arasında anlamlı bir ilişki olup olmadığını belirlemek için pearson korelasyon katsayısı incelenmiştir.

Katılımcı Ön Test Deyim-Son Test Deyim Puanları Arasındaki İlişkiye Ait Korelasyon Analizi Sonuçlarına Dair Bulgular

Tablo 8. Katılımcı Ön Test Deyim-Son Test Deyim Puanları Arasındaki Korelasyon Sonuçları

\begin{tabular}{llc}
\hline & & Son Test Deyim Puan \\
\hline \multirow{3}{*}{ Ön Test Deyim Puan } & $\mathrm{r}$ &, $389^{* *}$ \\
\cline { 2 - 3 } & $\mathrm{p}$ & 0,000 \\
\cline { 2 - 3 } & $\mathrm{N}$ & 80 \\
\hline
\end{tabular}

$* * \mathrm{p}<0.01$

Öğrencilerin ön test deyim puanları ile son test deyim puanları arasında anlamlı bir ilişki olup olmadığını belirlemek için pearson korelasyon katsayısı incelenmiştir.

Katılımcı Ön Test-Ön Test Deyim Puanları Arasındaki İlişkiye Ait Korelasyon Analizi Sonuçlarına Dair Bulgular

Tablo 9. Katılıme Ön Test-Ön Test Deyim Puanları Arasındaki İlişkiye Korelasyon Sonuçları

\begin{tabular}{ccc}
\hline & & Ön Test Deyim Puan \\
\hline \multirow{3}{*}{ Ön Test Puan } & $\mathrm{r}$ & 0,19 \\
\cline { 2 - 3 } & $\mathrm{p}$ & 0,092 \\
\cline { 2 - 3 } & $\mathrm{N}$ & 80 \\
\hline
\end{tabular}

Öğrencilerin ön test puanları ile ön test deyim puanları arasında anlamlı bir ilişki olup olmadığını saptamak için pearson korelasyon katsayısı incelenmiştir.

Katılımcı Son Test-Son Test Deyim Puanları Arasındaki İlişkiye Ait Korelasyon Analizi Sonuçlarına Dair Bulgular

Tablo 10. Katılımcı Son Test-Son Test Deyim Puanları Arasındaki Korelasyon Sonuçları

\begin{tabular}{llc}
\hline & & Son Test Deyim Puan \\
\hline \multirow{3}{*}{ Son Test Puan } & Pearson Korelasyon & 0,19 \\
\cline { 2 - 3 } & Sig. (2-tailed) & 0,091 \\
\cline { 2 - 3 } & $\mathrm{N}$ & 80 \\
\hline
\end{tabular}

Öğrencilerin son test puanları ile son test deyim puanları arasında anlamlı bir ilişki görülüp görülmediğini saptamak için pearson korelasyon katsayısı incelenmiştir. 


\section{Sonuç, Tartışma ve Öneriler}

Araştırmaya katılan 80 öğrenciden ön test ve son test toplam 640 yazılı kompozisyon örneği alınmıştır. $\mathrm{Bu}$ anlatımlarda toplam 906 deyim kullanıldığ 1 tespit edilmiştir. Yazılı anlatımlarda kullanılan deyim sayılarının öğrenciler arasında farklılık gösterdiği saptanmıştır. Örneğin kontrol grubu öğrencilerinden K5 kodlu öğrenci ön test yazılı anlatımlarında toplam 3 deyim kullanırken K38 kodlu öğrenci toplam 5 deyim kullanmıştır.

Ön test yazılı anlatımlarında kontrol grubundan bir öğrencinin (K37 kodlu öğrenci) yazılı anlatımlarında hiç deyim kullanmadığı görülmüştür. Aynı öğrencinin son test yazılı anlatımlarında yine hiç deyim kullanmadığı tespit edilmiştir. Ön test yazılı anlatımlarında deney grubundan iki öğrencinin yazılı anlatımında hiç deyim kullanmadığı saptanmıştır. Ancak son test yazılı anlatımlarında deney grubundaki her öğrencinin yazılı anlatımlarında en az bir deyim kullandığı saptanmıştır. Yapılan araştırma neticesinde, kontrol grubuna oranla deney grubunda deyim öğrenimi ve kullanımı açısından artış görülmüştür. Böylece kullanılacak farklı yöntemlerin ve çeşitli etkinliklerin deyim öğretimindeki başarıyı artırabileceği ortaya çıkmıştır. Çalışma kitaplarındaki deyim öğretimi etkinliklerinin öğrencilerde anlamlı bir öğrenme oluşturup oluşturmadığını tespit etmek amaçlayan Demirel İşbulan (2010, s. 59-60), elde ettiği veriler doğrultusunda deney grubuna uygulanan ve araştırmacı tarafından farklı öğretim tekniklerinden yararlanarak hazırlanan deyim öğretimi etkinliklerinin kontrol grubuna uygulanan çalışma kitaplarındaki etkinliklere göre daha anlamlı öğrenmeler sağladığı sonucuna ulaşmıştır.

Yapılan bağımsız örneklem t-testi sonucuna göre öğrencilerin ön test puanlarının cinsiyetlerine göre farklılığının istatistiksel olarak \%95 güven düzeyinde anlamlı olduğu saptanmıştır $(\mathrm{t}=2.484$, $\mathrm{p}=.015, \mathrm{p}<.05$ ). Öğrencilerin son test puanlarının cinsiyetlerine göre farklılığ istatistiksel olarak \%95 güven düzeyinde anlamlı olmadığı $(\mathrm{t}=.223, \mathrm{p}=.824, \mathrm{p}<.05)$, öğrencilerin ön test deyim puanlarının cinsiyetlerine göre farklılığı istatistiksel olarak \%95 güven düzeyinde anlamlı olmadığ $(\mathrm{t}=1.946$, $\mathrm{p}=.055, \mathrm{p}<.05)$ ve öğrencilerin son test deyim puanlarının cinsiyetlerine göre farklılı̆̆ 1 istatistiksel olarak 95 güven düzeyinde anlamlı olduğu $(\mathrm{t}=2.812, \mathrm{p}=.009, \mathrm{p}<.05)$ saptanmıştır.

Deyimin hikâyesini ve gerçek anlamını bilmenin cinsiyete göre etkileri incelendiğinde; kız ögrencilerin ön test puanlarının erkek öğrencilerinin ön test puanlarından yüksek olduğu tespit edilmiştir. Ancak öğrencilerin son test puanlarında cinsiyetlere göre farklılığın anlamlı olmadığı belirlenmiştir. Buna karşın öğrencilerin ön test deyim puanlarında cinsiyete göre farklılığın anlamlı olmadığı, ancak öğrencilerin son test deyim puanları incelendiğinde ise farklılığın anlamlı hâle geldiği gözlenmiştir. Kız öğrencilerin son test deyim puanlarının, erkek öğrencilerinin son test deyim puanlarından yüksek olduğu görülmektedir. $\mathrm{Bu}$ veriler neticesinde uygulanan yöntem erkek öğrencileri başarı testlerinde olumlu etkilerken kız öğrencileri ise yazılı anlatımda deyim kullanımı açisından olumlu yönde geliştirmiştir.

Şahin (2018)'in yaptığı araştırmada, öğrencilerin cinsiyeti ile hikâyesi olan deyimlerin drama yöntemi ile öğretilmesi başarı puanlarına ait ön test sonucunda istatistiksel olarak anlamlı bir farklılık saptanmamıştır (U=36.000; p>.05). Söz konusu araştırmaya katılan öğrencilerin cinsiyet ile hikâyesi olan deyimlerin drama yöntemi ile öğretilmesi başarı puanlarına ait son test sonucunda istatistiksel olarak anlamlı bir farklılık saptanmamıştır $(\mathrm{U}=44.000 ; \mathrm{p}>.05)$. Araştırmada, hikâyesi olan deyimlerin drama yöntemiyle öğretilmesinde öğrencilerin cinsiyetlerine göre kalıcılığını sorgulayan test sonucunda istatistiksel olarak anlamlı bir farklılık saptanmamıştır $(U=36.000 ; p>.05)$. 
Yapılan bağımsız örneklem t-testi sonucuna göre öğrencilerin ön test puanlarının gruplara göre farklılığ 1 istatistiksel olarak \%95 güven düzeyinde anlamlı olduğu belirlenmiştir ( $\mathrm{t}=-2.075, \mathrm{p}=.041$, $\mathrm{p}<.05$ ). Öğrencilerin son test puanlarının gruplara göre farklılığı istatistiksel olarak \%95 güven düzeyinde anlamlı olmadığ $1(\mathrm{t}=-.297, \mathrm{p}=.767, \mathrm{p}<.05)$, ön test deyim puanlarının gruplara göre farkl11ı̆̆ 1 istatistiksel olarak \%95 güven düzeyinde anlamlı olduğu $(\mathrm{t}=2.628, \mathrm{p}=.01, \mathrm{p}<.05)$ ve öğrencilerin son test deyim puanlarının gruplara göre farklılığının istatistiksel olarak \%95 güven düzeyinde anlamlı olmadığı tespit edilmiştir $(\mathrm{t}=1.179, \mathrm{p}=.242, \mathrm{p}<.05)$. Yapılan bağımlı örneklem t-testi sonuçlarına bakıldığında öğrencilerin ön test puanları ile son test puanları arasındaki farklılığın istatistiksel olarak $\% 95$ güven düzeyinde anlamlı olduğu tespit edilmiştir $(\mathrm{t}=-2.321, \mathrm{p}=.023, \mathrm{p}<.05)$.

Öğrencilerin ön test sonuçları ile son test sonuçları arasında pozitif yönlü anlamlı bir ilişki olduğu belirlenmiştir. Bununla birlikte ön test deyim puanları ile son test deyim puanları arasında da pozitif yönlü anlamlı bir ilişki olduğu görülmüştür. Öğrencilerin ön test puanlarının, son test puanlarından düşük olması ve son test yazılı anlatımlarında kullanılan deyim sayısının ön test yazılı anlatımlarında kullanılan deyim sayısından fazla olması deyimin hikâyesini ve geç̧ek anlamını bilmenin yazılı anlatım becerisi üzerinde etkisi olduğunu ve verilen eğitimin öğrenciler üzerinde etkili olduğunu göstermektedir.

Literatürde, deyim öğretimi ile ilgili yapılan bazı çalışmalar araştırmanın sonuçlarını destekler niteliktedir. Şenol, çalışmasında "Türkçe Öğretim Programında yer alan söz varlığını zenginleştirme amaç ve kazanımları içinde bulunan mecazi anlatım unsuru olan deyimlerimizi, hikâyelerini kullanarak yaratıcı drama yöntemiyle öğrenciye aktardığımızda daha etkili ve kalıcı bir öğrenme gerçekleştirmiş" (2011, s. 84) olunacağını belirtmiştir. Şahin (2018)'in yaptığı araştırmaya katılan öğrencilerin deney sonrası ölçülen son test hikâyesi olan deyimlerin drama yöntemi ile öğretilmesi başarı puanlarının deney öncesi ölçülen ön test hikâyesi olan deyimlerin drama yöntemi ile öğretilmesi başarı puanlarından daha yüksek olduğu görülmüştür. Çalışmada, araştırmaya katılan öğrencilerin hikâyesi olan deyimlerin drama yöntemi ile öğretilmesi başarı puanlarının ön test-son test puan ortalamaları arasında istatistiksel olarak anlamlı bir farklılık bulunmuştur $(Z=3.970 ; p<, 01)$. Şahin, elde ettiği bulgular neticesinde hikâyesi olan deyimlerin drama yöntemi ile öğretilmesi uygulamasının deyimleri daha kolay öğrenmede önemli bir etkisi olduğu sonucuna ulaşmıştır.

Öğrencilerin ön test deyim puanları ile son test deyim puanları arasındaki farklılığı istatistiksel olarak \%95 güven düzeyinde anlamlı olmadığ 1 saptanmıştır $(\mathrm{t}=1.762, \mathrm{p}=.082, \mathrm{p}<.05)$. Yapılan korelasyon analizi sonuçlarına göre ön test puanları ile son test puanları arasında istatistiksel olarak \%95 güven düzeyinde, pozitif yönlü düşük kuvvette anlamlı bir ilişki olduğu $(\mathrm{r}=.371, \mathrm{p}=.000, \mathrm{p}<.01)$, ön test deyim puanları ile son test deyim puanları arasında istatistiksel olarak \%95 güven düzeyinde, pozitif yönlü düşük kuvvette anlamlı bir ilişki olduğu $(\mathrm{r}=.389, \mathrm{p}=.000, \mathrm{p}<.01)$, ön test puanları ile ön test deyim puanları arasında istatistiksel olarak \%95 güven düzeyinde, anlamlı bir ilişki olmadığı $(\mathrm{r}=.19, \mathrm{p}=.092, \mathrm{p}<.01)$ ve son test puanları ile son test deyim puanları arasında istatistiksel olarak \%95 güven düzeyinde, anlamlı bir ilişki olmadığ tespit edilmiştir $(r=.19, \mathrm{p}=.091, \mathrm{p}<.01)$.

Bir sözcüğün ya da sözcük grubunun anlamının kavranabilmesi için sözcüğün kullanıldığı metin bağlamına ihtiyaç duyulmaktadır. Deyimlerin hikâyeleri ile birlikte verilmesi aynı zamanda deyimin bağlamı ile birlikte verilmesi anlamına gelmektedir. Ön test yazılı anlatımlarında kontrol grubunda toplam üç deyimin bağlama uygun kullanılmadığı belirlenmiştir. Kontrol grubunun son test yazılı anlatımlarında ise toplam dört deyimin bağlama uygun kullanılmadığı saptanmıştır. Ön test yazılı anlatımlarında deney grubunda iki deyimin bağlama uygun kullanılmadığ tespit edilirken son test yazılı anlatımlarında bir deyimin bağlama uygun kullanılmadığı belirlenmiştir. Bu araştırmada, verilen 
eğitimin öğrenciler üzerinde etkili olması, bağlamın sözcük ve sözcük gruplarını öğrenmede etkili bir yöntem olduğu sonucuna ulaşılmıştır.

Araştırmanın sonuçlarından hareketle öğretmenler ve araştırmacılarca uygulamalarda yapılan gözlemler neticesinde öğrencilerin deyim farkındalık düzeylerinin düşük olduğu görülmüştür. Öğrencilerde deyim farkındalığını artıracak etkinliklere ve bu yöndeki araştırmalara ağırlık verilmelidir. Deyimler mecazlı ve soyut söz varlıklarıdır. Deyim öğretiminde öğretmen, deyimleri bağlamlarıyla birlikte kullanmaya özen göstermelidir. Bu amaçla alanda yapılan çalışmalar takip edilmedir. Öğrencilerde deyim kullanımının ve ifade gücünün gelişmesi açısından deyimlerin yerli yerinde kullanıldığı edebî eserlerin okutulması faydalı olacaktır. Çalışma, deyim öğretimiyle sınırlandırılmıştır. Söz varlığını oluşturan atasözleri ve kalıplaşmış sözler için de benzer araştırmalar yapilabilir.

\section{Kaynakça}

Aksan, D. (2006a). Anadilimizin söz denizinde. Ankara: Bilgi Yayınevi.

Aksan, D. (2006b). Türkçenin sözvarlığı. Ankara: Engin Yayınevi.

Aksan, D. (2015). Her yönüyle dil ana çizgileriyle dil bilim. Ankara: Türk Dil Kurumu Yayınları.

Aksan, D. (2016). Anlambilim. Ankara: Bilgi Yayınevi.

Akyalçın, N. (2012). Türkçemizin anlamsal zenginlikleri deyimlerimiz. Ankara: Eğiten Kitap.

Aytaş, G. ve Çeçen, M. A. (2010). Ana dili eğitiminde dil bilgisi öğretiminin yeri ve önemi. Türklük Bilimi Araştırmaları Dergisi, XXVII (27), 77- 89.

Balaban, M. (2019). Ortaokul Türkçe derslerinde deyimlerin öğretiminde metinsel bağlamın etkisi. Yayımlanmamış Yüksek Lisans Tezi. Niğde Ömer Halisdemir Üniversitesi Eğitim Bilimleri Enstitüsü, Niğde.

Banguoğlu, T. (1979). Ana hatlarıyla Türk grameri. İstanbul: Dergâh Yayınları.

Baş, B. (2006). 1985-2005 Yılları arasında çocuk edebiyatı sahasında yazılmış tahkiyeli metinlerin söz varlığı üzerine bir araştırma. Yayımlanmamış Doktora Tezi. Gazi Üniversitesi Eğitim Bilimleri Enstitüsü: Ankara.

Bilgin, M. (2002). Anlamdan anlatıma Türkçemiz. Ankara: T.C. Kültür Bakanlığı Yayınları.

Çelik, Ş. (2006). Normal dağılım ve normal dağılımla ilgili çıkarımlar. Yayımlanmamış Yüksek Lisans Tezi. Ankara Üniversitesi Fen Bilimleri Enstitüsü, Ankara.

Emir, S. (1974). Örnekleriyle açıklamalı deyimler sözlüğü. İstanbul: Emir Yayınları.

Ergin, M. (1972). Türk dil bilgisi. İstanbul: Boğaziçi Yayınları.

George, D \& Mallery, M. (2010). SPSS for windows step by step: a simplw study guide and reference, 17.0 Update. Boston: MA: Allyn \& Bacon.

Gülcan, F. (2010). Deyim öğretiminde gösteri tekniğinin etkililiği. Yayımlanmamış Yüksek Lisans Tezi. Sakarya Üniversitesi Sosyal Bilimler Enstitüsü, Sakarya.

Günay, D. (2007). Sözcükbilimine giriş. İstanbul: Multilingual. 
Hengirmen, M. (2011a). Atasözleri sözlüğü. Ankara: Engin Yayınları.

İşbulan, Z. (2010). 7. Sınıf Türkçe çalışma kitaplarındaki deyimlerin öğretiminde kullanılan etkinliklerin etkililiği. Yayımlanmamış Yüksek Lisans Tezi. Sakarya Üniversitesi Sosyal Bilimler Enstitüsü, Sakarya.

Kazıcı, E. (2008). İlköğretim ikinci kademe Türkçe derslerinde deyim ve atasözlerinin öğretiminde dramatizasyon yönteminin etkililik düzeyi. Yayımlanmamış Yüksek Lisans Tezi. Selçuk Üniversitesi Sosyal Bilimler Enstitüsü, Konya.

Korkmaz, Z. (1992). Gramer terimleri sözlüğü, Ankara: TDK Yayınevi.

Korkmaz, Z., Ercilasun, A., Akalın, M., Gülensoy, T., Zülfikar, H. Parlatır, İ. ve Birinci, N. (1995). Yüksek öğretim öğrencileri için Türk dili ve kompozisyon bilgileri. Ankara: YÖK

Özbay, M. (2013). Türkçe öğretimi üzerine araştırma ve incelemeler. Ankara: Öncü Kitap.

Özbay, M. ve Akdağ, E. (2013). Deyimlerin öğretiminde aktif öğrenmenin etkisi. Ana Dili Eğitimi Dergisi, 1(2), 46-54.

Pala, İ. (2018). İki Dirhem Bir Çekirdek. İstanbul: Kapı Yayınları.

Sülükçü, Y. (2011). Yabanc1lara Türkçe öğretiminde (temel seviye a1) bilgisayar destekli materyal geliştirme ve bunun öğrenci başarısına etkisi. Yayımlanmamış Doktora Tezi. Selçuk Üniversitesi Eğitim Bilimleri Enstitüsü, Konya.

Şahin, T. G. (2018). Hikâyesi olan deyimlerin drama yöntemiyle öğretilmesi. Yayımlanmamış Yüksek Lisans Tezi. Frrat Üniversitesi Eğitim Bilimleri Enstitüsü, Elâzı̆̆g.

Şenol, Z. (2011). Deyimlerin yaratıcı drama yöntemiyle öğretimi. Yayımlanmamış Yüksek Lisans Tezi. Atatürk Üniversitesi Eğitim Bilimleri Enstitüsü, Erzurum.

Ünalan, Ş. (2010). Dil ve kültür. Ankara: Nobel Yayıncılık.

Yakıc1, A., Yücel, M., Doğan, M. ve Yelok, S. (2017). Üniversiteler için Türkçe-1 yazılı anlatım. Ankara: Yarg1 Yayınevi.

Yalçın, A. (2018). Son bilimsel gelişmeler 1şı̆̆ında Türkçenin öğretimi yöntemleri. Ankara: Akçağ Yayınları.

Yıldız, C. (Ed). (2013). Yeni öğretim programına göre kuramdan uygulamaya Türkçe öğretimi. Ankara: Pegem Akademi. 